
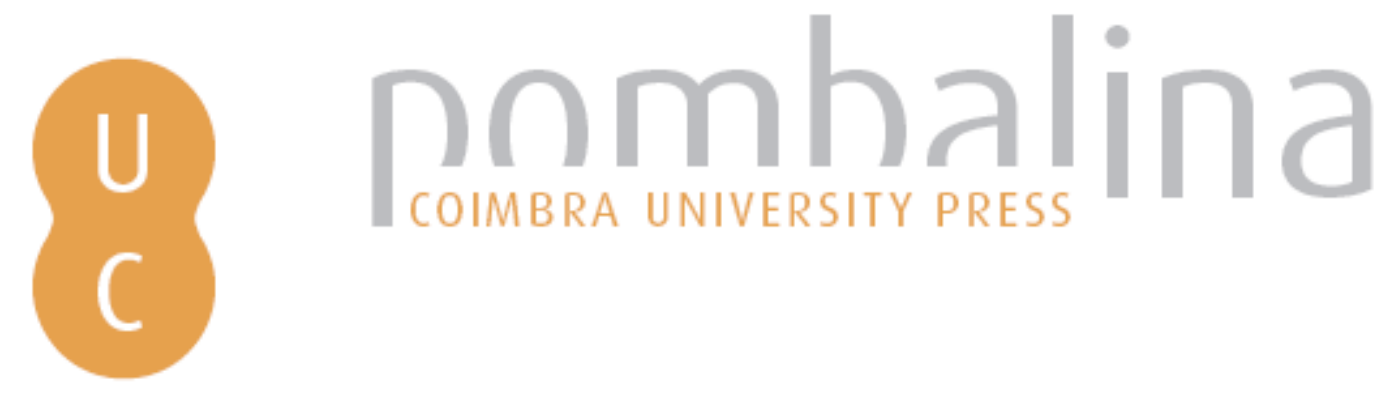

\title{
Darwin and Mereschkowsky: two images, two evolutionary concepts
}

Autor(es): $\quad$ Santos, Ricardo S. Reis dos; Carrapiço, Francisco

Publicado por: Imprensa da Universidade de Coimbra

URL

persistente:

URI:http://hdl.handle.net/10316.2/31281

DOI:

DOI:http://dx.doi.org/10.14195/978-989-26-0342-1_11

Accessed : $\quad$ 26-Apr-2023 14:41:21

A navegação consulta e descarregamento dos títulos inseridos nas Bibliotecas Digitais UC Digitalis, UC Pombalina e UC Impactum, pressupõem a aceitação plena e sem reservas dos Termos e Condições de Uso destas Bibliotecas Digitais, disponíveis em https://digitalis.uc.pt/pt-pt/termos.

Conforme exposto nos referidos Termos e Condições de Uso, o descarregamento de títulos de acesso restrito requer uma licença válida de autorização devendo o utilizador aceder ao(s) documento(s) a partir de um endereço de IP da instituição detentora da supramencionada licença.

Ao utilizador é apenas permitido o descarregamento para uso pessoal, pelo que o emprego do(s) título(s) descarregado(s) para outro fim, designadamente comercial, carece de autorização do respetivo autor ou editor da obra.

Na medida em que todas as obras da UC Digitalis se encontram protegidas pelo Código do Direito de Autor e Direitos Conexos e demais legislação aplicável, toda a cópia, parcial ou total, deste documento, nos casos em que é legalmente admitida, deverá conter ou fazer-se acompanhar por este aviso.

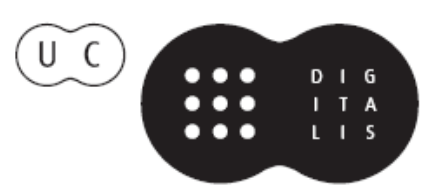


Ana Leonar Pereira João Rui Pita

Pedro Ricarda Fonseca (eds.)
Darwin,

Evalution,

Evolutionisms

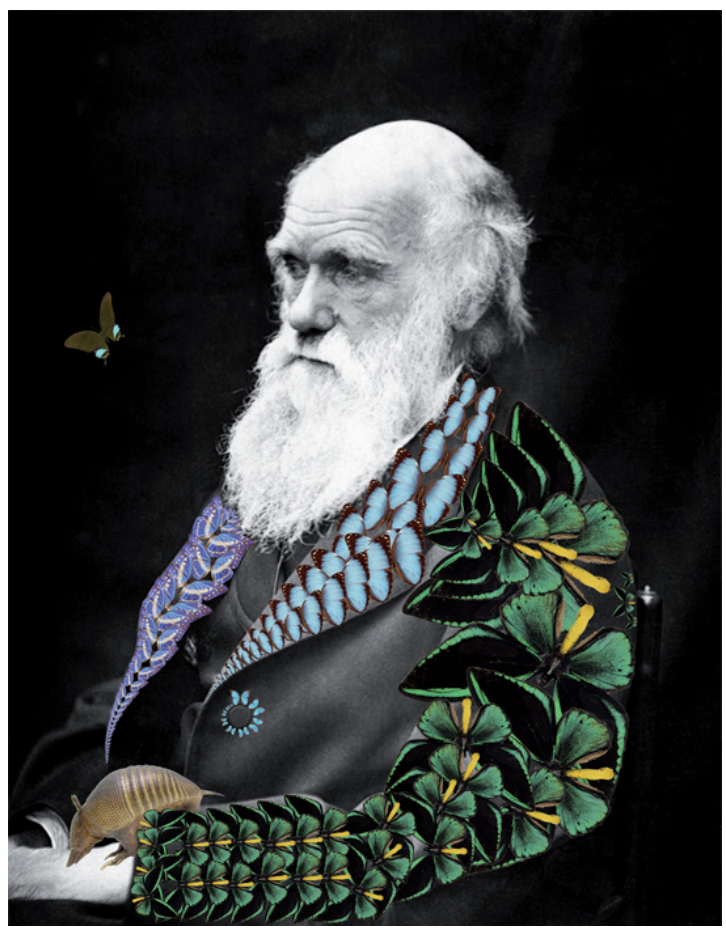


Ricardo S. Reis dos Santos

Centro de Filosofia das Ciências, Faculdade de Ciências, Universidade de Lisboa, Portugal

Francisco Carrapiço

Faculdade de Ciências, Departamento de Biologia Vegetal, Centro de Biologia Ambiental, Centro de Filosofia das Ciências, Universidade de Lisboa, Portugal

DARWIN AND MERESCHKOWSKY:

Two IMAges, TWO EVOLUTIONARY CONCEPTS

\section{Introduction}

With the publication of The Origin of Species, in 1859, the English naturalist Charles Darwin (1809-1882) revolutionized all Western thought. Regarding science, natural selection positioned itself as a paradigmatic mechanism for explaining biological evolution, and which, over time, was incorporated into new epistemological conceptions (e.g. Darwinism, neo-Darwinism, social Darwinism). In 1909, only fifty years after the publication of Darwin's important work, the Russian biologist Constantin Mereschkowsky (1855-1921) introduced the concept of symbiogenesis as an alternative explanatory mechanism for the evolution of life. In both cases, Darwin and Mereschkowsky illustrate their concepts through images. In this work we will focus on Darwin's and Mereschkowsky's epistemological experiences in the conceptual explanations of the evolution of life. We will also pay special attention to the epistemological value of image as proximity operator in the representation of concepts.

\section{The tree and the evolutionary concept of Darwin}

With the publication of $O n$ the Origin of Species, Darwin had in mind two distinct objectives: "first, to show that species were created separately, and secondly, to show that natural selection was the main agent of change (...)» (Darwin, quoted in Gould, 1989). The verb «to show» does not appear here by accident. In fact, it underlines Darwin's intentions of exposing, showing, making visible, evident, what he considered being the «mystery of mysteries»: the origin and evolution of species. Darwin considered his work «a long argument» which had as a guideline precisely those two above-mentioned objectives. Thus, his intention was «to show» that species were created separately, and "to show» that natural selection was the main agent of change. In this sense, Darwin was accurate in the way he «showed" those two objectives. In its hundreds of pages, The Origin of Species includes only a small illustration - a treelike diagram - although Darwin considered the publication of this diagram «indispensable» (Darwin, quoted in Smith, 2006). Actually, this image represents, in a summarised manner, not only the so-called textual «long argument», which serves as a contextualizing element, but also and mainly "to show" the effects of natural selection on the descendants of a common ancestor, and in particular «to show» the principle of divergence. 


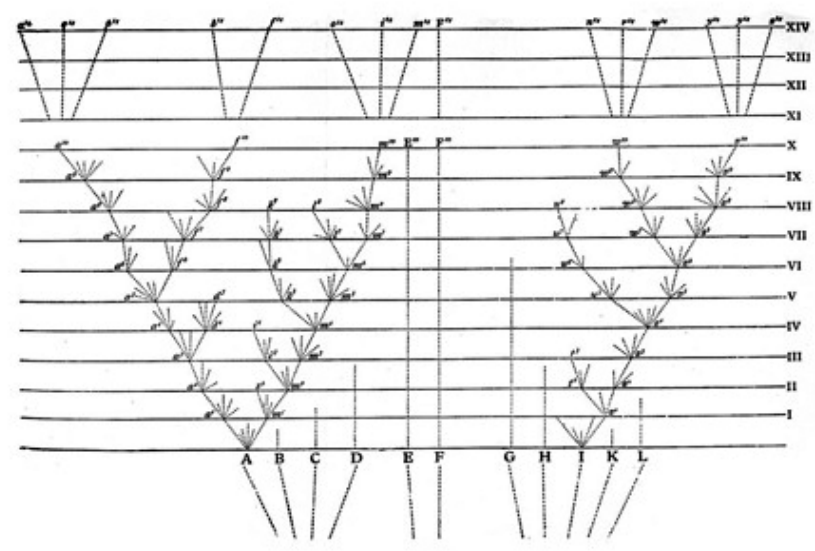

Figure 2. Charles Darwin's Diagram, On the Origin of Species (London: Murray, 1859), between pages 116 and 117

(C) Wellcome Library, London

Darwin's diagram (fig. 1) appears here as an interesting thought-experiment. The letters A and L represent the species of a vast gender that inhabits a particular geographical region. Each horizontal line represents a thousand, or more, generations, allowing for a vertical reading in relation to time. The punctuated lines go from A to I and are gradually ramified, representing different variations, which appear in the descendents. When one of these lines crosses the horizontal line, a small letter with a number above the line of the text indicates that sufficient variations occurred to form a distinct variety. This process continues by the horizontal line X, from which Darwin presents a condensed and simplified version of the same process. Here, we can observe that, at the end of ten thousand generations, the species A evolved into three distinct species $(\mathrm{a} 10, \mathrm{f} 10, \mathrm{~m} 10)$. After fourteen generations, it originated eight species (from a14 to m14). However, the original species A, as well as all the species and intermediate varieties, were extinct. The species B, C and D survived at least during a certain time. Just one species, F, survived during fourteen thousand generations. Of the eleven initial species presented (A to L), fifteen species emerged, very different and more distinct than the previous ones. In fact, so distinct, according to Darwin, that we can imagine the last descendants from A to I as two separate genders or at least sub-genders (Smith, 2006).

The diagram does not represent all of the evolution theory by natural selection, but ends up «showing» in a very objective manner, along with the due contextualization, Darwin's evolutionary concept. In summary, a concept characterised by a mechanism which acts passively and which is exterior to the individual. In fact, a mechanism which considers that the organisms are in constant competition due to the scarceness of resources, organisms which, due to their intra and inter-specific variations present a differential adaptation, that is, natural selection ends up preserving the better adapted organisms to a certain environment. In this sense, the species, as an individual, appear here as a selection unit and evolution occurs vertically. 
The tree and the evolutionary concept of Mereschkowsky

In 1909, fifty years after the publication of On the Origin of Species, Mereschkowsky published in the Proceedings Studies of the Imperial Kazan University a paper titled The Theory of Two Plasms as Foundation of Symbiogenesis. A New Doctrine on the Origins of Organisms ${ }^{1}$, where he introduces for the first time the concept of symbiogenesis: "the origin of organisms by the combination or the association of two or more beings which enter in symbiosis» (Mereschkowsky, 1909, quoted in Carrapiço \& Rita, 2009). Symbiosis, according to the definition introduced in 1879 by Anton De Bary (1831-1888), means «the joint life of different organisms» (De Bary, 1879, quoted in Carrapiço \& Rita, 2009). In Mereschkowsky’s paper, similarly to Darwin's important work, is presented a diagram with the shape of a tree with the intention of «showing» the concept of symbiogenesis (fig. 2).

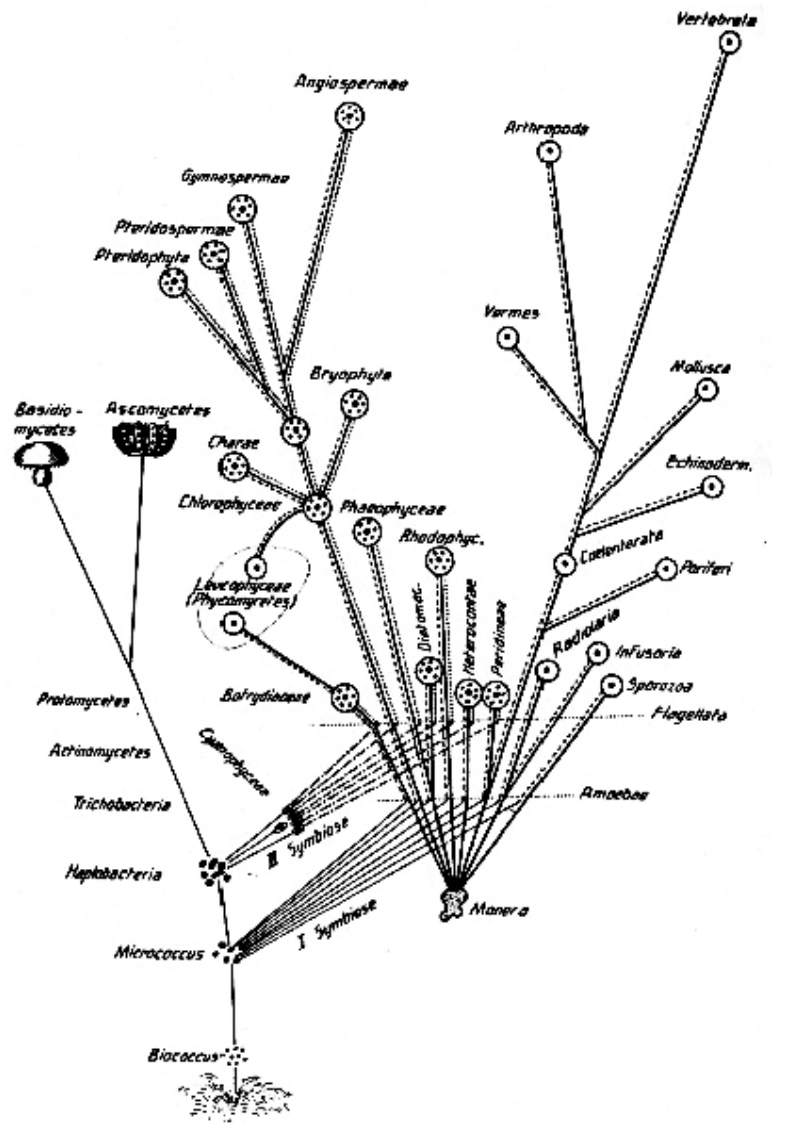

Figure 3. Diagram of Constantin Mereschkowsky, Theorie der zwei Plasmaarten... (1910), page 366

1 The original article was written in Russian. One year later, Mereschkowsky published the same article in German. 
This diagram, similar to Darwin's one, also reveals an experience of thought. If we compare it to the one published in The Origin of Species, we see two substantial differences: first, there are two evident starting points which lead to two distinct evolutionary lines of organisms equally distinct; second, there is a horizontal connection between these two evolutionary lines. These two innovations highlight a theory which Mereschkowsky had already developed in 1905 in an article entitled Uber Natur und Ursprung der Chromatophoren im Pflanzenreich [on the nature and origin of chromatophores (plastids) in the plant kingdom], where he defends for the first time that chloroplasts had originated from free-living cyanobacteria; in fact, a theory which Mereschkowsky will dedicate most of his lifetime, despite opposition of all the currents of that time (Carrapiço \& Rita, 2009).

The concept of symbiogenesis proposed by Mereschkowsky remained submerged until the middle of the 1960's, when Lynn Margulis (1938-2011), after several attempts, publishes an article entitled On the Origin of Mitosing Cells (Sagan, 1967) in which she develops the Serial Endosymbiosis Theory, bringing to scientific debate symbiogenic ideas. The theory developed by Margulis establishes a discontinuity among prokaryotic and eukaryotic cells, and essentially considers that mitochondria, basal bodies, flagella and chloroplasts derived from free-living prokaryotic cells, leading eukaryotic cells to be seen as the result of the evolution of primitive symbiosis (Carrapiço \& Rita, 2009). In fact, the sequential endosymbiosis theory by Margulis is no more than a sort of "modern synthesis" of Mereschkowsky's symbiogenesis theory.

The epistemological implications of this concept are very interesting since symbiogenesis created new units of selection - symbiomes $^{2}-$ which appear through the integration of various parts, followed by the progressive differentiation of the whole, conferring, thus, a competitive advantage which goes beyond the traditional neo-Darwinism selection (Carrapiço, 2009). On the other hand, symbiogenesis presents not only an evolutionary mechanism in which symbiosis occurs as a vehicle of that organism, but presents itself also as a decisive operator in the production of innovative metabolic and anatomic variation on which the own natural selection can act later on.

\section{Conclusion}

The corollary of the natural selection mechanism is based on the principle that evolution occurs by a competitive process in which only the better adapted organisms are preserved. In this sense, natural selection occurs in the interface between the organism (and all its heredity charge) and the environment in which it is inserted. As a result, natural selection acts on the phenotype of the individual and has no intervention in the machine that produces variation, being limited to its preservation

\footnotetext{
${ }^{2}$ The introduction of symbiomes in scientific terminology was a conceptual change in the traditional view which has been transmitted on the structure and function of organisms, with profound consequences in biological, medical and social domains. In this perspective, each plant and each animal have to be considered as a "superorganism" - symbiome - which includes its own genes existing in chromosomes, the genes of cellular organelles (mitochondria and/or chloroplasts), as well as the genetic information of symbiont bacteria and the virus which lives in the organism. Concept introduced by Jan Sapp in 2003 (Carrapiço, 2003).
} 
or elimination. In other words, the variation is a fact for which, according to Buffon, "there is no other solution than of the fact itself" (Jacob, 1981). However, according to this mechanism, evolution occurs in a gradual and unidirectional manner along a vertical line with origin in one point. On the other hand, the symbiogenic concept, introduced by Mereschkowsky, came to show that natural selection is not the only explanatory mechanism of biological evolution. In fact, there is more and more evidence of the multiple origins of life and horizontal gene transfer between different phylogenetic branches. Symbiogenesis positions itself as an evolutionary mechanism that does not exclude natural selection but has cooperation at its basis. In this sense, symbiogenesis can be hereby understood as a mechanism of producing difference. This differentiation results from the horizontal fusion of two or more distinct entities, which present different capabilities from their individual components, forming the so-called symbiome (Carrapiço \& Rita, 2009). As a result, and without despising the excellence of Darwin's and Mereschkowsky's absolutely notorious contributions, we consider it is important to refer that the two evolutionary concepts here presented probably constitute restricted aspects of a universal law. And for that reason, we should argue that no system will explain life in all its aspects and all its details.

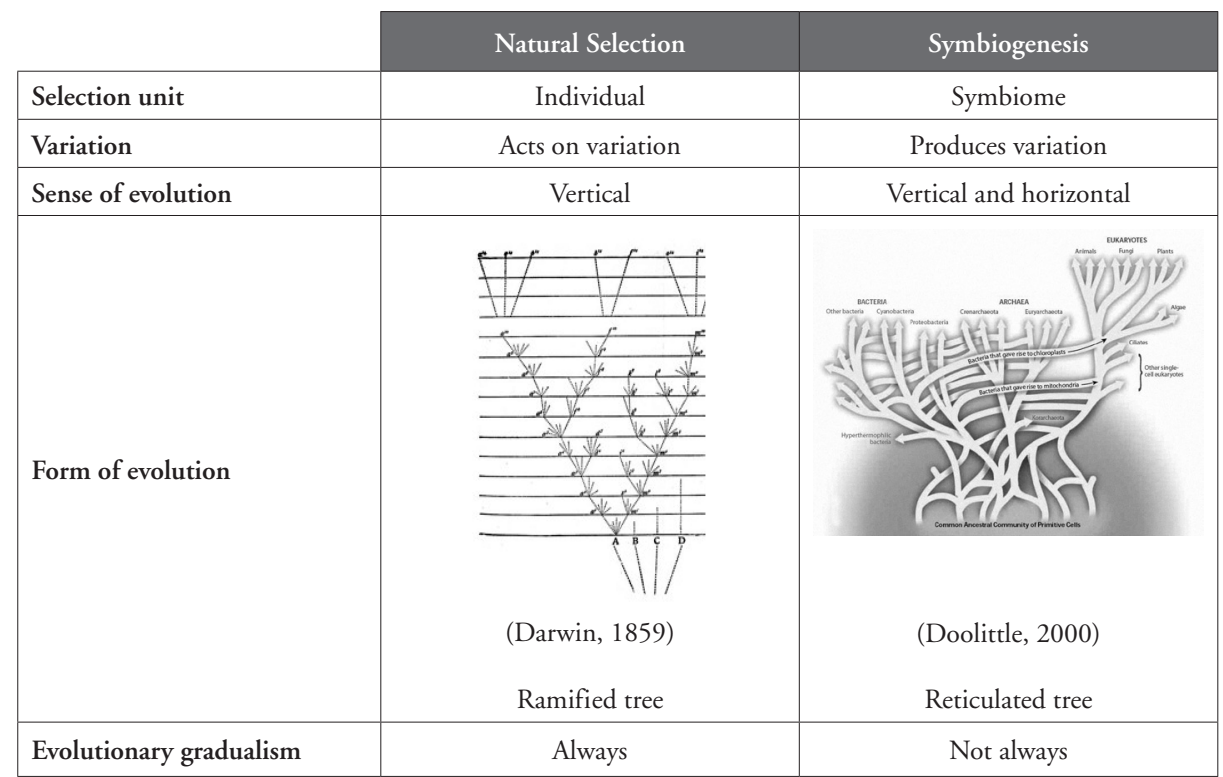

Table 1. Comparison between Natural Selection and the Symbiogenesis in its main aspects.

In a recent article, entitled An extended evolutionary synthesis, Pigliucci \& Levy (2009) declare that «since Modern Synthesis, little has been advanced theoretically that is, Modern Synthesis constitutes a base-structure of current and future evolutionary biology, without there being a great need to revisit its fundaments» Such claim argues, thus, for an expansion of that synthesis without altering the paradigm. The same authors claim that the Modern Synthesis (the theoretical restructuration of original 
Darwinism as a new discipline of Mendelian genetics and statistics) carried out in the 1930's and 1940's, did not correspond, as defended by Mayr, to a shift of paradigm in the Kuhnian sense of the word, but instead to a true synthesis of areas that, at that time, were in opposite sides (Pigliucci \& Levy, 2009). This theoretical advancement, as we have seen, occurred fifty years after the publication of The Origin of Species. This theoretical advancement implied, or should have implied, or will imply, a paradigm shift. Curiously, this shift can be represented by two images - Darwin's and Mereschkowsky's treelike diagrams - as representative marks of two distinct but not exclusive evolutionary concepts. In this sense, both Darwin and Mereschkowsky realized the importance of image in its ability to visualize the unseen, that is, the outcome of a process (evolution) that cannot for whatever reason be performed in the laboratory.

\section{Bibliography}

CARRAPIÇO, F. - Introdução a alguns conceitos. Available at http://azolla.fc.ul.pt, 2003 (access on $1^{\text {st }}$ of May 2009)

CARRAPIÇO, F. - The Symbiotic Phenomenom in the Evolutive Context. In Pombo, Rahman, Torres \& Simon (eds) Unity of Science: Essays in Honour of Otto Neurath. Springer, 2011

CARRAPIÇO, F. \& RITA, O. - Simbiogénese e evolução. In Levy, Carrapiço, Abreu e Pina (eds). Evolução. Conceitos e Debates, Lisbon: Esfera do Caos, 2009, 175-198

DARWIN, C. - On the Origin of Species by Means of Natural Selection. $1^{\text {st }}$ Edition. London: John Murray, 1859 (disponível em http://darwin-online.org.uk)

GOULD, S. J. - Quando as galinhas tiverem dentes. Lisbon: Gradiva, 1989

JACOB, F. - O Jogo dos Possíveis. Ensaio sobre a Diversidade do Mundo. Lisbon: Publicações Gradiva, 1981

PIGLIUCCI, M. \& LEVY, A. - Uma síntese evolutiva expandida. In Levy, Carrapiço, Abreu e Pina (eds). Evolução. Conceitos e Debates, Lisbon: Esfera do Caos, 2009, 199-219

SAGAN, L. - On the Origin of Mitosing Cells, Theoret. Biol. (1967) 14, 225-274

SAPP, J., CARRAPIÇO, F. \& ZOLOTONOSOV, M. - Symbiogenesis: The Hidden Face of Constantin Merezhkowsky. Hist. Phil. Life Sci, 24 (2002), 413-440

SMITH, J. - Charles Darwin and Victorian Visual Culture. Cambridge: Cambridge University Press, 2006 